\title{
ANALISA PENGENDALIAN PERSEDIAAN BAHAN BAKU PADA PT. INCASI RAYA PESISIR SELATAN
}

\author{
Tri Ernita ${ }^{1}$, Ali Sutan Nasution ${ }^{2}$, Duwel Tanjung ${ }^{3}$ \\ 1,2,3 Teknik Industri, Sekolah Tinggi Teknologi Industri STTIND Padang \\ email: : triernita@sttind.ac.id
}

\begin{abstract}
Abstrak: Tujuan dari Penelitian ini untuk mengetahui pengendalian persedian bahan baku pada PT. Incasi Raya Pesisir Selatan. Metode yang digunakan dalam mencapai tujuan analisis data adalah dengan menggunakan metode Economic Order Quantity. Hasil penelitian dari pembelian yang optimum dengan kebijakan perusahaan adalah 312 kali, sedangkan dengan menggunakan metode Ergonomic oerder kuantity yaitu 208 kali. Total biaya persediaan dengan menggunakan kebijakan perusahaan adalah Rp 8.746.878,- setelah menggunakan metode Ergonomic Order Kuantity dapat mengefesiensikan besarnya biaya persedian perusahaan yaitu Rp 8.078.649,-. Dengan persediaan pengaman adalah sebanyak 2.335 ton dan titik pemesanan ulang sebesar 3.763 ton
\end{abstract}

Kata Kunci: Bahan Baku, EOQ, Pengendalian Persediaan.

Abstract: The purpose of this study was to determine the control of the supply of raw materials at PT. Raya Pesisir Selatan Incasi. The method used in achieving data analysis objectives is to use the Economic Order Quantity method. The optimum research result with company policy is 312 times, whereas using the Ergonomic Oerder Quantity method is 208 times. The total cost of inventory using company policy is Rp 8,746,878, - after using the Ergonomic Order Quantity method, it can streamline the amount of company supply costs, namely Rp. 8.078,649, -. With a safety stock of 2,335 tons and a reorder point of 3,763 tons

Keywords: Raw Materials, EOQ, Inventory Control.

\section{PENDAHULUAN}

Dalam menerapkan sistem pengendalian persediaan bahan baku bagi perusahaan, ada beberapa faktor yang mempengaruhi dari persediaan bahan baku tersebut, Salah satu faktor tersebut yaitu perkiraan pemakaian bahan baku, biaya persediaan dan waktu tunggu pemesanan. Jumlah atau tingkat persediaan bahan baku yang dibutuhkan oleh perusahaan berbeda-beda untuk setiap perusahaan atau pabrik, tergantung dari volume produksinya, jenis pabrik, dan prosesnya.

Mengendalikan persediaan yang tepat bukan hal yang mudah. Apabila jumlah persediaan terlalu besar mengakibatkan timbulnya dana menganggur yang besar yang tertanam dalam persediaan, meningkatkan biaya penyimpanan, dan risiko kerusakan barang yang lebih besar. Namun jika persediaan itu terlalu sedikit, mengakibatkan risiko terhambatnya kegiatan operasi perusahaan khusunya proses produksi. Pada dasarnya semua perusahaan mengadakan perencanaan dan pengendalian bahan dengan tujuan pokok menekan (meminimumkan) biaya dan untuk memaksimumkan laba dalam waktu tertentu

\section{METODE PENELITIAN}

EOQ (Economic OrderQuantity )

Digunakan untuk menentukan kuantitas pesanan persediaan yang meminimumkan biaya langsung penyimpanan persediaan dan biaya kebalikannya (inverse cost) pemesanan persediaan

Rumus EOQ yang biasa digunakan adalah :

$$
\mathrm{EOQ}=\sqrt{\frac{2 \mathrm{DS}}{\mathrm{H}}}
$$




\section{Safey Stock}

Menentukan persediaan pengaman digunakan analisa statistik yaitu dengan mempertimbangkan penyimpangan penyimpangan yang telah terjadi antara perkiraan pemakai bahan baku dengan pemakaian sebenarnya sehingga diketahui standar deviasinya.

Adapun rumus standar deviasi adalah sebagai berikut (Purwanto dan Suharyadi 2007 : 136):

$$
\begin{aligned}
& \mathrm{SD}=\sqrt{\frac{\sum(x-\bar{x})^{2}}{n}} \\
& \text { Keterangan : } \\
& \mathrm{SD}=\text { Standar deviasi } \\
& x=\text { Jumlah permintaan } \\
& \bar{x}=\text { Jumlahrata-ratapermintaan } \\
& \quad \text { bahan baku } \\
& \mathrm{n}=\text { Jumlah data }
\end{aligned}
$$

Sedangkan rumus yang digunakan untuk menghitung persediaan pengaman adalah sebagai berikut :

$$
\begin{aligned}
& \mathrm{SS}=\mathrm{SD} \times \mathrm{Z} \\
& \text { Keterangan : } \\
& \mathrm{SS}=\text { Persediaan pengaman (Safety } \\
& \quad \text { Stock) } \\
& \mathrm{SD}=\text { Standar deviasi } \\
& \mathrm{Z}=\quad \begin{array}{l}
\text { Faktor pengaman yang } \\
\text { digunakan perusahaan }
\end{array}
\end{aligned}
$$

Titik pemesanan kembali (ROP)

Reorder Point (ROP) adalah pada tingkat persediaan berapa pemesanan harus dilakukan agar barang datang tepat pada waktunya. Adapun rumus dari ROP (Reoder Point) adalah

\begin{tabular}{|c|c|c|}
\hline No & Biaya & Rincian \\
\hline 1 & $\begin{array}{c}\text { Biaya } \\
\text { admnitrasi }\end{array}$ & $3,200,000$ \\
\hline 2 & Biaya telepon & $2,850,000$ \\
\hline & Total & $6,050,000$ \\
\hline
\end{tabular}

$\mathrm{ROP}=\mathrm{d} \times \mathrm{L}+\mathrm{SS}$

Keterangan :
ROP : ReOrder Point (titik pesan kembali)
D : Pemakaian bahan baku rata- rata perhari
L : : Waktu tunggu
SS : Persediaan pengaman

\section{HASIL DAN PEMBAHASAN}

Table 1. RealisasiPersediaanBahan Baku

\begin{tabular}{rlcr}
\hline & & Target & \\
No & Tahun 2017 & Persediaan & Persediaan \\
\hline 1 & Januari & 19,000 & 15,686 \\
2 & Februari & 19,000 & 18,735 \\
3 & Maret & 18,500 & 17,426 \\
4 & April & 19,500 & 20,187 \\
5 & Mei & 18,500 & 18,971 \\
6 & Juni & 19,000 & 16,405 \\
7 & Juli & 19,000 & 18,332 \\
8 & Agustus & 19,000 & 19,176 \\
9 & September & 19,500 & 20,173 \\
10 & Oktober & 19,000 & 19,452 \\
11 & November & 19,500 & 20,292 \\
12 & Desember & 19,000 & 17,884 \\
\hline & Total & 228,500 & 222,718 \\
\hline
\end{tabular}

Sumber: PT. Incasi Raya Pesisir Selatan

Tabel 2. BiayaPemesanan Tahun2017

Tabel 3. Biaya Penyimpanan 2017

\begin{tabular}{ccc}
\hline No & Biaya & Rincian \\
\hline & Biaya perawatan \\
1 & gudang & $650,700,000$ \\
2 & Biaya listrik & $850,300,000$ \\
3 & Biaya penjaga & $116,800,000$ \\
4 & Biaya Asuransi & $65,000,000$ \\
\hline & Total & $1,682,800,000$ \\
\hline
\end{tabular}

Sumber: PT. Incasi Raya PesisirSelatan

\section{Untuk Mengetahui Bagaimana Pembelian Bahan Baku yang Ekonomis}

a. Kebutuhan Bahan Baku Kebutuhan bahan baku pada PT. Incasi Raya Pesisir Selatan tahun 2017 sebanyak 222,718 ton, Jadi jumlah pembelian rata-rata bahan 
baku selama setahun yang di lakukan pada PT. Incasi Raya adalah sebagai berikut:

Jumlah kebutuhan bahan baku

$=\frac{\text { kebutuhan bahan baku }}{\text { frekuensi pembelian }}$

$=\frac{222.718 \text { ton }}{312}$

$=713,84$ ton $/$ hari

Jadi jumlah kebutuhan bahan baku menurut kebijakan perusahaan adalah sebesar 713,84 ton.

b. Biaya Pemesanan (Ordering Cost) Biaya pemesanan merupakan biaya yang langsung terkait dengan kegiatan pemesanan bahan baku yang dilakukan perusahaan. Komponen biaya pemesanan terdiri dari biaya administrasi dan biaya telepon.

Perhitungan biaya pemesanan

$=\frac{\text { Total Biaya pemesanan }}{\text { frekuensi pemesanan }}$

$=\frac{R p 6.050 .000}{312}$

$=\operatorname{Rp} 19.391,-$ / perpesanan

Jadi biaya pemesanan sekali pesan adalah Rp 19.391,-

c. BiayaPenyimpanan

Biaya yang harus dikeluarkan oleh perusahaan berupa biaya perawatan gudang, biaya listrik, biaya Penjaga dan biaya asuransi adalah sebagai berikut:

Perhitungan biaya penyimpanan

$=\frac{\text { Total Biaya penyimpanan }}{\text { Jumlah Kebutuhan Bahan Baku }}$

$=\frac{R p 1.682 .800 .000}{222.718 \text { Ton }}$

Biaya untuk penyimpanan $=\mathrm{Rp}$ 7.556,- / ton

d. Total Biaya Persediaan

Agar dapat menghitung biaya persediaan maka terlebih dahulu diketahui :

1. Total kebutuhan bahan baku (D) = 222.718 ton

2. Biayapemesanan sekali pesan (S) = Rp 19.391,-
3. Biayasimpan per Ton $(\mathrm{H})=\mathrm{Rp}$ 7.556,- / ton

4. Kuantitas pemesanan $\left(\mathrm{Q}^{*}\right)=$ 713,84 ton

TIC $=\left[\frac{D}{Q} S\right]+\left[\frac{Q}{2} H\right]$

$$
\begin{aligned}
= & {\left[\frac{222.718}{713,84} R p 19.391,-\right]+} \\
& {\left[\frac{713,84}{2} R p 7.556,-\right] } \\
= & \operatorname{Rp~6.049.990,-~+~}
\end{aligned}
$$

Rp 2.696.888,-

$=$ Rp 8.746.878,- / tahun

Jadi total biaya persediaan bahan baku PT. Incasi Raya apa bila menggunakan kebijakan perusahaan adalah $\mathrm{Rp}$ 8.746.878,-

\section{Persediaan Bahan Baku Menggunakan EOQ}

1. Mengetahui pembelian bahan baku yang ekonomis $E O Q$

a. Jumlah pembelian bahan baku yang optimal

$$
\begin{aligned}
& \text { Hal }- \text { hal yang harus } \\
& \text { diperhitungkan dalam } \\
& \text { menggunakan metode EOQ ini } \\
& \text { adalah sebagai berikut: } \\
& \text { 1. Total kebutuhan bahan baku (D) } \\
& =222.718 \text { ton }
\end{aligned}
$$

2. Biayapemesanan sekali pesan (S)

$$
=\operatorname{Rp} 19.391,-
$$

3. Biayasimpan per Ton $(\mathrm{H})$

$$
=\operatorname{Rp~7.556,-~/~ton~}
$$

Maka setelah diketahui

hal seperti yang tercantum diatas, besarnya pembelian bahan baku yang ekonomis menggunakan metode EOQ adalah sebagai berikut:

$$
\begin{aligned}
& \mathrm{Q}^{*}=\sqrt{\frac{2 D S}{H}} \\
& =\sqrt{\frac{2 \times 222.718 \times 19.391}{7.556}} \\
& =1.069 \text { ton } / \text { hari }
\end{aligned}
$$

Jadi jumlah pembelian bahan baku yang ekonomis dengan menggunakan metode EOQ adalah sebesar 1.069 ton. 
b. Perhitungan frekuensi pembelian yang optimal

Dengan diketahuinya $Q^{*}$ yang optimal maka juga dapat dicari jumlah pemesanan tahunan atau frekuensi pembelian yang optimum. $\mathrm{F}=\frac{D}{\mathrm{Q} *}$

$\mathrm{F}=\frac{222.718}{1.069}=208,34 \approx 208$

Jadi frekuensi pembelian yang optimum adalah sebanyak 208 kali per tahun.

c. Total biaya persediaan yang optimal Hal - hal yang harus diperhitungkan dalam menggunakan metode EOQ ini adalah sebagai berikut :

1. Total kebutuhan bahan baku (D) $=222.718$ ton

2. Biaya pemesanan sekali pesan (S) =Rp 19.391,-

3. Biaya penyimpanan per Ton (H) $=$ Rp 7.556,- / ton

4. Pembelian bahan baku yang ekonomis $\left(\mathrm{Q}^{*}\right)=1.069$ ton

$$
\begin{aligned}
& \text { TIC }=\left[\frac{D}{Q} S\right]+\left[\frac{Q}{2} H\right] \\
= & {\left[\frac{222.718}{1.069} R p 19.391,-\right]+} \\
& {\left[\frac{1.069}{2} R p 7.556,-\right] } \\
= & \operatorname{Rp} 4.039 .967+ \\
& \operatorname{Rp} 4.038 .682 \\
= & \operatorname{Rp~8.078.649,-~/~tahun~}
\end{aligned}
$$

Jadi total biaya persediaan bahan baku PT. Incasi Raya apa bila menggunakan metode $E O Q$ adalah Rp 8.078.649,-

\section{Mengetahui persediaan pengaman yang harus di sediakan (Safety Stock)}

Safety stock sangat diperlukan guna menunjang kelancaran proses produksi yang berlangsung, seperti halnya menghindari kekurangan bahan baku yang akan mengakibatkan proses terhenti dan karyawan tidak bekerja. Hal ini sangat merugikan pihak perusahaan. Perhitungan standar deviasi dapat dilihat pada tabel 4 berikut :
Tabel 4.Perhitungan Standar Deviasi Bahan Baku Tahun 2017

\begin{tabular}{clccl}
\hline Tahun & & & & \\
2017 & $X$ & $X$ & $X$ & $(X-X)^{-2}$ \\
\hline Januari & 15,686 & 18560 & $-2,874$ & $8,259,876$ \\
Februari & 18,735 & 18560 & 175 & 30625 \\
Maret & 17,426 & 18560 & $-1,134$ & 1285956 \\
April & 20,187 & 18560 & 1,627 & 2647129 \\
Mei & 18,971 & 18560 & 411 & 168921 \\
Juni & 16,405 & 18560 & $-2,155$ & 4644025 \\
Juli & 18,332 & 18560 & -228 & 51984 \\
Agustus & 19,176 & 18560 & 616 & 379456 \\
September & 20,173 & 18560 & 1,613 & 2601769 \\
Oktober & 19,452 & 18560 & 892 & 795664 \\
November & 20,292 & 18560 & 1,732 & 2999824 \\
Desember & 17,884 & 18560 & -676 & 456976 \\
\hline Total & 222,718 & & & $24,322,205$ \\
\hline
\end{tabular}

Dimana:

$$
\mathrm{SD}=\sqrt{\frac{\sum(x-\bar{x})^{2}}{n}}
$$

$\mathrm{SD}=$ Standar deviasi

$x=$ Jumlah permintaan

$\bar{x}=$ Jumlah rata - rata permintaan bahan baku

$$
\begin{aligned}
\mathrm{SD} & =\sqrt{\frac{\sum(x-\bar{x})^{2}}{n}} \\
& =\sqrt{\frac{24,322,205}{12}} \\
& =\sqrt{2026850,42} \\
& =1.424 \text { Ton }
\end{aligned}
$$

Dengan menggunakan perkiraan bahwa perusahaan memenuhi permintaan sebanyak $95 \%$ dan persediaan cadangan 5 $\%$, maka diperoeh $\mathrm{Z}$ dengan tabel normal sebesar 1.64 deviasi standar dari rata-rata.

Rumus untuk menghitung persediaan pengaman

$\mathrm{SS}=\mathrm{SD} \times \mathrm{Z}$

Keterangan:

SS:Safety Stock (persediaan pengaman)

SD : Standar Deviasi

$\mathrm{Z}$ : Nilai a 5\% yang dilihat pada tabel distribusi normal.

Dengan demikian besarnya kuantitas persediaan pengaman (safety stock) adalah: 


$$
\begin{aligned}
& =1.424 \text { ton } \mathrm{x} 1,64 \\
& =2.335 \text { ton }
\end{aligned}
$$

Jadi persediaan pengaman yang harus di sediakan oleh perusahaan adalah sebesar 2.335 ton.

\section{Mengetahui titik pemesanan kembali (Re Order Point)}

Reorder Point (ROP) adalah titik pemesanan kembali dengan Persediaan Pengaman $=2.335$ ton

Jumlah hari kerja dalam setahun

$=312$ Hari

Jumlah Pemakaian Bahan baku

$=222.718$ Ton

Pemakaian bahan baku

$=\underline{222.718}=713,84$ ton

$$
312
$$

Dengan demikian besarnya ROP yaitu:

$\mathrm{ROP}=(713,84 \times 2)+2.335$

$$
=3.763 \text { Ton }
$$

\section{Analisa Hasil Pengolahan Data}

Dari hasil pengolahan data dengan penerapan metode EOQ diharapkan dapat membantu perusahaan untuk memperkecil biaya persediaan bahan baku, dengan tahapan menghitung total dan rata-rata kebutuhan bahan baku TBS, menghitung biaya pesan per pesanan (S), menghitung biaya penyimpanan per ton bahan baku $(\mathrm{H})$, setelah diketahui nilai $\mathrm{S}$ dan $\mathrm{H}$, barulah bisa mencari besarnya pembelian bahan baku yang ekonomis $\mathrm{Q}^{*}$, menghitung frekuensi pembelian optimal, menghitung total biaya persediaan, persediaan pengaman (Safety Stock) dan titik pemesanan kembali $(R O P)$.

\section{Hasil Analisa Pengendalian Produksi Menggunakan $\mathrm{EOQ}$}

a. Analisa pembelian bahan baku yang ekonomis $E O Q$

Berdasarkan penelitian dan wawancara yang dilakukan di PT.Incasi Raya Pesisir Selatan bahwa perusahaan tersebut memproduksi dua jenis produk yaitu Crude Palm Oil (CPO) dan Inti ( Kernel ). Analisis EOQ ini dapat digunakan untuk menghemat biaya persediaan. Dalam menerapkan metode EOQ ada beberapa biaya yang harus dipertimbangkan dalam penentuan jumlah pembelian diantaranya:

1. Biaya Pemesanan

Biaya pesan adalah untuk bahan baku tandan buahsegar (TBS) perusahaan mengeluarkan biaya administrasi sebagai biaya pemesanannya. Pada PT.Incasi Raya Pesisir Selatan pemesanan TBS tidak direncanakan atau tidak dijadwalkan, sistem pengadaan bahan baku hanya tergantung pemasok yang ingin menjual TBS nya, jadi setiap pemasok yang menjual TBS akan selalu diterima. Untuk setiap pemasok yang masuk, perusahaan mengeluarkan biaya administrasi dan telefon sebesar Rp 19.391 / perpesanan

2. Biaya Penyimpanan

Selain biaya pemesanan perusahaan juga mengeluarkan biaya penyimpanan sebagai akibat kegiatan menyimpan bahan baku TBS di gudang dalam periode waktu tertentu. Pada PT. Incasi Raya biaya sewa gudang tidak dihitung sebagai biaya penyimpanan karena gudang adalah milik perusahaan yang merupakan investasi sebagai aset perusahaan. Biaya pergudangan yang terdiri atas biaya perawatan gudang, biaya tenaga kerja, biaya listrik dan biaya asuransi, dibebankan dalam biaya penyimpanan bahan baku. Jadi biaya penyimpanan hanya terdiri dari biaya admistrasi, yaitu sebesar Rp 7.556 / ton. Maka yang tercantum di atas, akan diketahui besarnya pembelian bahan baku yang ekonomis menggunakan EOQ adalah sebesar 1.069 ton. Selanjutnya juga akan bisa dicari perhitungan frekuensi pemesanan. Dalam perhitungan mencari frekuensi didapatkan hasilnya 
sebesar 208,34dan dibulatkan menjadi 208 kali

\section{Total Biaya Persediaan}

Total biaya persediaan menurut EOQ yaitu sebesarRp 8.078.649,-Total biayatersebutdapat di caridengancaratotal kebutuhan bahan baku222.718 tondi bagidenganPembelianbahanbaku yang ekonomis 1.069 tondi kali denganBiaya pemesanan sekali pesan $\mathrm{Rp}$ 19.391. maka di dapatlahhasilnyaRp

4.039.967selanjutnya di lakukanperhitungankembaliyaituPe mbelianbahanbaku yang ekonomis 1.069 ton di bagi 2 di kali Biayasimpan per TonRp 7.556 / ton maka di dapatkan hasilnya adalah Rp 4.038.682 dari jumlah tersebut maka di tambah dengan $\mathrm{Rp}$ 4.039.967, hasilnya adalahRp 8.078.649,-.

\section{Analisa Persediaan Pengaman yang Harus di Sediakan (Safety Stock)}

Perusahaan dalam melakukan pemesanan suatu barang sampai barang datang memerlukan jangka waktu yang bisa berbeda-beda setiap bulannya. Hal ini sering disebut dengan lead time yaitu jangka waktu yang diperlukan sejak dilakukan pemesanan sampai saat datangnya bahan baku yang dipesan. Untuk mengetahui seberapa lamanya lead time biasanya diketahui dari lead time pada pemesanan-pemesanan sebelumnya. Kebiasaan para pemasok menyerahkan bahan baku yang akan dipesan apakah tepat waktu atau terlambat. Bila sering terlambat berarti perlu safety stock yang besar, sebaliknya bila biasanya tepat waktu maka tidak perlu safety stock yang besar. Dalam perhitungan persediaan pengaman (Safety Stock) digunakan metode statistik dengan memperbandingkan rata-rata bahan baku dengan pemakaian bahan baku yang sesungguhnya kemudian dicari penyimpangannya. Perhitungan standar deviasi, dengan total $(X-\bar{X})=24,322,205$. Dan hasil perhitungan Standar Deviasi adalah sebesar 1.424 Ton.

Dengan menggunakan perkiraan atau asumsi bahwa perusahaan memenuhi permintaan sebanyak $95 \%$ dan persediaan cadangan 5\%. Yang berarti perusahaan memiliki tingkat keyakinan akan memenuhi permintaan sebanyak 95\%, dan tingkat kesalahan 5\%. Kenapa 95\%, kenapa tidak $90 \%$ atau $99 \%$ ? Karena $95 \%$ adalah tingkat keyakinan yang normal. Lalu akan diperoleh nilai $\mathrm{Z}$ dengan tabel normal 1.64 deviasi standar dari rata-rata. Nilai Safety Stock yang dihitung adalah sebesar 2.335 ton .

\section{Analisa titik pemesanan kembali (Re Order Point)}

Reorder Point (ROP) adalah strategi operasi persediaan yang merupakan titik pemesanan yang harus dilakukan suatu perusahaan sehubungan dengan adanya Lead Time dan Safety Stock.Lamanya waktu tenggang atau lead time PT.Incasi Raya adalah 2 hari dimana waktu operasi dalam satu tahun adalah 312 hari, maka nilai ROP yang dihasilkan adalah sebesar 3.763ton. Jadi perusahaan akan kembali memesanbahan baku jika persediaan bahan baku mencapai 3.763 Ton.

\section{KESIMPULAN}

Berdasarkan pengolahan dan analisa data yang telah dilakukan pada bab IV dan bab V maka dapat disimpulkan hasil dari penelitian yang telah dilakukan adalah sebagai berikut:

1. Dari hasil penelitian diketahui bahwa besar pembelian bahan baku TBS yang paling ekonomis adalah sebesar 1.069 tondan frekuensi pembelian bahan baku yang optimum adalah sebanyak 208kali dalam setahun.

2. Biaya persediaan bahan baku adalah sebesar Rp 8.078.649,-

3. Jumlah persediaan pengaman (Safety Stock) adalah sebesar 2.335 ton. 
4. Perusahaan harus melakukan pemesanan kembali (Reorder Point) pada tingkat persediaan sebesar 3.763 Ton.

\section{DAFTAR PUSTAKA}

Assauri, Sofyan. Manajemen Produksi dan Operasi, Jakarta: Lembaga Penerbit Fakultas Ekonomi UI. 2008.

Fahmi, Irham. Manajemen Produksi dan Operasi. Bandung: Alfabeta.2014.

Handoko, T. Hani. Dasar - dasar Manajemen Operasi. Yogyakarta: BPFE.2012.

Handoko, T. Hani. Dasar-dasar Manajemen Produksi dan Operasi. BPFE. Yogyakarta, 2000.

Herjanto, Eddy.2008. Manajemen Operasi, Edisi Kesembilan Buku 2. Jakarta: Salemba Empat.

Indrajit, R.E dan R. D Pranoto. Manajemen Persediaan. PT. Gramedia Widiasarana Indonesia. Jakarta, 2003.

Mudjarad. Metode Riset Untuk Bisnis dan Ekonomi. Jakarta: Erlangga Margaretha, 2009.

Pahan,Iyung. Kelapa Sawit, Manajemen Agribisnis Dari Hulu Hingga Hilir. Cetakan III. Jakarta. Penebar Swadaya 2008

Rizka, S. Kelapa Sawit Upaya Peningkatan Produktivitas. Yogyakarta. Penerbit Kanisius. 1993

Pangestu.Manajemen Operasi.Yogyakarta:BPFE.2011.
Slamet, Achmad. Penganggaran Perencanaan dan Pengendalian Usaha. UNNES PRESS. Semarang, 2007.

Sudana, I Made.Manajemen Keuangan Perusahaan Teori dan Praktik.Jakarta: Erlangga.2011.

Sugiyono.Statistika

Untuk

Penelitian,Bandung: 2010.

Sumayang, Lalu. Dasar-dasar Manajemen Produksi dan Operasi. Salemba Empat. Jakarta, 2003.

Sunarko. Petunjuk Praktis Budidaya dan Pengolahan Kelapa Sawit. Agromedia Pustaka. Jakarta. 2007 